\title{
PARADOXOS DO DIREITO DE VIVER E DE MORRER
}

\author{
Gabriel Gualano de Godoy* \\ Rebeca Fernandes Dias*
}

RESUMO: Este trabalho propõe uma análise crítica dos direitos de viver e de morrer. No decorrer do texto são identificadas as normas brasileiras que pretendem, ou pretenderam, tratar da eutanásia. Depois de identificá-las, foram desenvolvidos alguns argumentos que problematizem as posições contrárias e favoráveis à eutanásia. Conscientes da insuficiência dos parâmetros modernos buscou-se tirar o véu dos paradoxos que envolvem as diversas perspectivas de valorização da vida, bem como da rede de poderes existente em torno desta mesma valorização (o biopoder, ou melhor, a biopolítica).

\section{INTRODUÇÃO}

O homem moderno, racional, pleno de si, centro do universo e do ordenamento jurídico, vive uma crise. Parece que, ao mesmo tempo em que busca transcender todos os seus limites, orgânicos, intelectuais e de valores, toma consciência de sua insignificância individual.

Essa ambigüidade pode ser mais bem compreendida quando se olha com maior atenção para o significado dos avanços da

* Gabriel Gualano de Godoy e Rebeca Fernandes Dias são mestrandos em Direito das Relações Sociais do Programa de Pós-graduação em Direito da UFPR, bolsistas da CAPES e pesquisadores dos Núcleos: Direitos Humanos e Democracia e Direito e Subjetividade. biotecnologia. Para além das promessas de um mundo melhor, o que a tecnociência coloca em xeque são questões tradicionalmente entendidas pela humanidade como sagradas e inevitáveis, como a vida e a morte.

$\mathrm{O}$ direito de viver e a certeza de morrer ganharam nova configuração em uma era de contornos pós-humanos. O anúncio para um futuro próximo da recriação dos conceitos de vida e morte exigem, desde já, alguma reflexão por parte dos juristas.

O presente artigo assume essa missão ao abordar um tema específico, o da eutanásia.

A palavra eutanásia deriva da etimologia grega: $e u$, que significa boa, e thanatos, que significa morte; trata-se, portanto, da boa morte, de uma morte sem sofrimentos. 
Francis Bacon teria inaugurado o emprego do termo no mundo moderno para designar a "ação de um médico que 'fornece ao doente, quando já não há esperança, uma morte doce e pacífica"". 1

A medicina, unida à tecnologia, há algum tempo desenvolve meios de aumentar a expectativa de vida e de prolongar o processo de morte de uma pessoa.

Entretanto, já em 1974,

"três cientistas de fama mundial, o inglês George Thompsom, o americano Linus Pauling e o francês Jacques Monod, todos laureados com o Nobel, assinaram uma declaração a favor da 'eutanásia humanitária' (beneficient euthanasia), isto é, na sua definição, 'uma morte rápida, sem dor e considerada um benefício pelo interessado".'.

O manifesto gerou diversas repercussões, especialmente no hemisfério norte, onde foram criadas muitas associações pelo direito de morrer com dignidade, ou pela eutanásia voluntária.

Por isso mesmo, estudar a eutanásia deve significar mais que uma análise jurídica sobre o poder de decisão de um sujeito de direito, sobre sua autonomia e dignidade, ou sobre até que ponto esta autonomia do indivíduo rompe com valores e direitos fundamentais ditos indisponíveis.

São várias as polêmicas e conturbados os questionamentos de ordem ética e moral que fazem o Direito parecer obsoleto, tendo-se em vista que muitas de suas ficções jurídicas não mais dão conta da realidade.

\footnotetext{
${ }^{1}$ HOTTOIS, Gilbert; PARIZEAU, Marie-Hélène. Dicionário da bioética. Lisboa: Instituto Piaget, 1998, p.226.

2 Idem, p.227.
}

$\mathrm{Na}$ era da proliferação dos direitos humanos, certas perguntas perturbam e permanecem carentes de respostas prontas, como, por exemplo: seria o direito à própria morte integrante do rol dos direitos fundamentais? Caberia ao Estado fornecer um acervo ético-legal que dê resposta positiva a alguém que deseja morrer? Até que ponto seria aceitável manter a vida de uma pessoa em condições degradantes? A partir de quando a vida deixaria de ser um direito e passaria a ser um tormento para um paciente terminal?

O presente trabalho não tem fôlego suficiente para fornecer soluções definitivas a tais indagações, mas, mesmo assim, buscará problematizá-las, brevemente, de maneira a tratar a questão da eutanásia sob um prisma crítico e interdisciplinar, uma vez que o assunto transcende o universo jurídico.

Isso será feito da seguinte maneira: no decorrer do texto são identificadas as normas brasileiras que pretendem, ou pretenderam, tratar da eutanásia; depois de identificá-las, serão desenvolvidos alguns argumentos que tratem de questionar as posições contrárias e favoráveis à eutanásia.

\section{EUTANASIA E NORMAS BRASILEIRAS}

Contemporaneamente, no Brasil, a prática da eutanásia consiste em um crime. Tendo sido praticada por médico, familiar ou terceiro, é considerada homicídio, na forma privilegiada, por ter sido cometido por motivo de relevante valor social ou moral, com diminuição de pena de um sexto a um terço (conforme o artigo 121, parágrafo primeiro, do Código Penal Brasileiro). Curioso observar que o consentimento do 
enfermo é indiferente, não havendo, portanto, distinção entre a eutanásia dita voluntária (na qual há o consentimento do paciente) e a involuntária (na qual há um ato paternalístico, em que o terceiro, julgando ser o melhor para o doente, pratica o ato eutanásico sem o consentimento deste).

Todavia, algumas tentativas de legalização mediante apresentação de Projetos de Lei já tramitaram no Congresso Nacional. Ocorre que a maioria destes Projetos se encontram arquivados, como se verá a seguir.

No ano de 1983, o deputado Inocência Oliveira apresentou um Projeto de Lei (PL-732/1983), segundo o qual se permitia "ao médico-assistente o desligamento dos aparelhos médicos de uma paciente em coma terminal ou na omissão de uma medicação que iria prolongar inutilmente uma vida vegetativa, sem possibilidade de recuperar condições de vida sofrível, em comum acordo com os familiares". O projeto exigia, ainda, que o fato deveria ser oficiado ao Conselho Regional de Medicina, com a descrição do quadro clínico do paciente. A Comissão de Constituição e Justiça decidiu pela inconstitucionalidade do projeto, que acabou sendo arquivado.

Houve uma outra tentativa de disciplinar a eutanásia, em 1984, com o Anteprojeto de Reforma da Parte Especial. Este Anteprojeto pretendia inserir no texto do Código Penal Brasileiro, artigo 121, parágrafo $3^{\circ}$, a seguinte previsão: "Não constitui crime deixar de manter a vida de alguém, por meio artificial, se previamente atestada, por dois médicos, a morte como iminente e inevitável, e desde que haja consentimento do doente ou, na sua impossibilidade, de ascendente, descendente, cônjuge ou irmão". ${ }^{3}$ Entretanto, a parte especial não chegou a ser reformada, atingindo a reforma apenas a parte geral do Código.

Em 1991, o deputado Gilvam Borges apresentou outro Projeto de Lei (PL - 1989/ 1991). Neste Projeto a eutanásia seria permitida nos casos de pacientes terminais sem chance de recuperação das funções neurocerebrais, cuja morte clínica tenha sido configurada. Há previsão das pessoas permitidas a fazerem a solicitação (cônjuge ou companheiro, filhos naturais e adotivos, ascendentes e o próprio paciente). O Projeto previa ainda que o paciente que tivesse atestado por dois médicos menos de seis meses de vida poderia requerer administração de drogas para a abreviação da vida. Tal projeto restou igualmente arquivado, em 1993, com fundamento na inconstitucionalidade de seu conteúdo.

Neste mesmo ano, Gilvam Borges propôs um projeto de Decreto Legislativo (PDL 244/1993) segundo o qual se convocava um plebiscito para que os habilitados a votar decidissem sobre a conveniência ou não de se instituir a eutanásia como forma de abreviar sofrimentos de pacientes terminais. Mas tal Projeto também foi declarado inconstitucional e veio a ser arquivado em 1994.

Gilvam Borges, em 1996, elaborou um outro Projeto de Lei (PL - 125/1996) na tentativa de disciplinar os casos em que se

\footnotetext{
${ }^{3}$ BORGES, Roxana Cardoso Brasileiro. Direito de morrer dignamente: eutanásia, ortotanásia, consentimento informado, testamento vital, análise constitucional e penal e direito comparado. In: SANTOS, Maria Celeste Cordeiro Leite (Org.). Biodireito: ciência da vida, os novos desafios. São Paulo: Revista dos Tribunais, 2001. p.292.
} 
poderia autorizar a prática da morte sem dor e os respectivos procedimentos prévios à sua consecução. Este Projeto previa a permissão de desligamento de aparelhos no caso de constatação de morte cerebral e a permissão de morte sem dor de pacientes em circunstâncias de sofrimento físico e mental excessivos, caso em que não se justificaria a continuidade de assistência médica. O Projeto previu a necessidade de consentimento prévio do paciente e, na impossibilidade deste, dos familiares e pessoas habilitadas à solicitação. Contudo, este Projeto encontra-se arquivado desde 1999.

Atualmente, tramita no Congresso Nacional o projeto de reforma do Código Penal, que pretende disciplinar a eutanásia da seguinte forma:

\section{"Dos crimes contra a vida HOMICÍDIO \\ Art. 121: EUTANÁSIA}

Parágrafo $3^{\circ}=$ Se o autor do crime é cônjuge, companheiro, ascendente, descendente, irmão ou pessoa ligada por estreitos laços de afeição à vítima e, agiu por compaixão, a pedido da vítima, imputável e maior, para abreviar-lhe sofrimento físico insuportável, em razão de doença grave e em estado terminal, devidamente diagnosticados:

Pena - reclusão, de dois a cinco anos". ${ }^{4}$

Dessa maneira, a eutanásia passaria a integrar o rol das qualificadoras do crime de homicídio. O projeto faz, ainda, menção à ortotanásia, determinando a sua antijuridicidade (art. 121, $\$ 4^{\circ}$ ): "Não constitui crime deixar de manter a vida de

${ }^{4}$ BRANDÃO NETO, Demercindo. Eutanásia. In: PETROIANU, Andy (Org.). Ética, moral $e$ deontologia médicas. Rio de Janeiro: Guanabara Koogan, 2003. p.253. alguém por meio artificial, se previamente atestada por dois médicos a morte como iminente e inevitável e desde que haja consentimento do paciente ou, em sua impossibilidade, de cônjuge, companheiro, ascendente, descendente ou irmão".

Outro Projeto de Lei (PL - 5058/2005) em trâmite no Congresso Nacional, de iniciativa do deputado Osmânio Pereira, pretende regulamentar o artigo 226, parágrafo $7^{\circ}$ da Constituição, dispondo a inviolabilidade do direito à vida, definindo a eutanásia e a interrupção voluntária da gravidez como crimes hediondos, em qualquer caso. ${ }^{5}$

O Código Brasileiro de Deontologia Médica, de 1984, coloca entre as infrações previstas realizadas por médicos: "Contribuir para apressar a morte do paciente, ou usar meios artificiais quando comprovada a morte cerebral" (art. 29). Percebe-se neste artigo a preocupação com a responsabilidade do médico em relação a sua atividade e ao seu paciente, mas este dispositivo não parece abarcar a prática eutanásica, uma vez que o artigo se revela bastante genérico e carece de previsão dos elementos necessários para a sua configuração.

O Código de Ética Médica brasileiro é também expressamente contra qualquer prática eutanásica. Isso pode ser comprovado

${ }^{5}$ Nesse sentido, ver a declaração de Luiz Flávio Borges D'URSO, que se posiciona radicalmente contra qualquer tipo de legalização da eutanásia: “(...) sou radicalmente contra a legalização da eutanásia no Brasil e a Holanda que acaba de legalizar a eutanásia, mais uma vez nos dá exemplo do que não se deve legalizar. Na Holanda as drogas são legalizadas, admite-se casamento entre pessoas do mesmo sexo, etc. (D’URSO, Luiz Flávio Borges. A eutanásia no Brasil. Disponível em: http:// www.direitopenal.adv.br>. Acessado em: 10 abr. 2002). 
com a leitura de seu artigo 66, que assim dispõe: "É vedado ao médico utilizar, em qualquer caso, meios destinados a abreviar a vida do paciente, ainda que a pedido deste ou de seu responsável legal".

Uma prática que pode se assemelhar à eutanásia e que já teve regulação em antigos ordenamentos é o suicídio. Contudo, na regulamentação jurídica pátria do suicídio assistido costuma-se não focar a conduta do suicida, mas sim da pessoa que o induz, instiga ou auxilia. Dessa forma, o Código Criminal do Império do Brasil (1830), em seu artigo 198, punia o auxílio ao suicídio com uma pena de dois a seis anos: "Ajudar alguém a se suicidar, ou fornecer-lhe meios para esse fim com conhecimento de causa". Porém, não havia punição do ato do suicídio ou de sua tentativa.

O Código Penal de 1890, em seu artigo 299, previa pena de prisão de dois a seis anos para a pessoa que induzisse ou ajudasse moral ou materialmente alguém a suicidar-se, devendo ocorrer a efetiva morte do suicida para que a conduta fosse considerada crime (como é atualmente).

O Código Penal em vigor, desde 1940, em seu artigo 122, estabelece a seguinte disposição:

\section{"Induzimento, instigação ou auxílio ao suicídio}

Art. 122. Induzir ou instigar alguém a suicidarse ou prestar-lhe auxílio para que o faça:

Pena - reclusão, de 2 (dois) a 6 (seis) anos, se o suicídio se consuma; ou reclusão, de 1 (um) a 3 (três) anos, se da tentativa de suicídio resulta lesão corporal de natureza grave".

Praticado por motivo egoístico, ou sendo a vítima menor ou, ainda, se a vítima tiver, por qualquer causa, a sua capacidade de resistência diminuída, a pena será duplicada, conforme estabelece o parágrafo único.

Partindo desta ótica, o suicídio assistido no direito brasileiro é crime, e encaixa-se na hipótese deste artigo, em seu tipo objetivo "prestar-lhe auxílio para que o faça", uma vez que no suicídio assistido a terceira pessoa apenas fornece os meios para que o próprio enfermo cometa o suicídio, tendo, portanto, uma conduta acessória, pois não participa da execução e consumação do ato.

Registre-se o interessante questionamento de Maura Roberti a respeito da tipificação desta conduta e da disponibilidade do direito à vida. Ela parte de dois pontos: ser a vida um direito indisponível (não sendo válido o consentimento de alguém para tirar-lhe a vida) e não ser considerado crime o suicídio e a tentativa. Sendo assim, ela questiona:

\footnotetext{
"Diante destas premissas, seria correto afirmarmos que, contrario sensu, a vida é um bem disponível se suprimida espontânea e voluntariamente, por pessoa com capacidade de entender e discernir? Em sendo positiva a resposta, por que então se tipifica a conduta daquele que auxilia alguém que, não tendo mais condições físicas, em razão de sofrimento inestimável ou por estar desenganada, pretende de forma livre, consciente, voluntária e espontânea, suprimir a própria vida?"6
}

\section{PARADOXOS DA EUTANASIA}

Antes de se falar no direito de morrer, seja a morte tida como um direito, como uma conseqüência, ou como um rito, é preciso pensar sobre o viver, sobre o significado do direito de todas as pessoas a ter uma vida digna.

\footnotetext{
${ }^{6}$ ROBERTI, Maura. Disponível em: <www.ibap.org/ direitopenal/mr-eutanasia.htm>. Acessado em: 3 mar. 2004.
} 
Apesar de ter sido enfrentada por muitos teóricos, definir o que é vida se trata de tarefa difícil. O jurista Antônio Chaves traduz o conceito de vida como sendo "algo que oscila entre um interior e um exterior, entre uma alma e um corpo". 7 Para José Afonso da Silva:

"a vida humana (...) integra-se de elementos materiais (físicos e psíquicos) e imateriais"; sua riqueza significativa é de difícil apreensão porque é algo dinâmico, que se transforma incessantemente sem perder sua própria identidade. É mais um processo (processo vital), que se instaura com a concepção (ou germinação vegetal), transforma-se, progride, mantendo sua identidade, até que muda de qualidade, deixando, então, de ser vida para ser morte. Tudo que interfere em prejuízo deste fluir espontâneo e incessante contraria a vida." 8

Esse oscilar entre um exterior e um interior, ou esse processo vital, é protegido e resguardado pelo ordenamento jurídico Moderno, que consagrou a vida como um bem, como um valor integrante do homo juris.

O direito à vida está previsto no rol de direitos fundamentais elencados na Constituição Federal, em seu artigo $5^{\circ}$, caput, juntamente com o direito à liberdade, à igualdade, à segurança e à propriedade. No artigo $1^{\circ}$, III, da Constituição, elegeu-se a dignidade da pessoa humana como um principio fundamental da Republica, que deve guardar uma relação conectada e inseparável de todas as outras normas.

Outros artigos e incisos da Carta Constitucional fazem referência ao direito à vida protegendo-a,

${ }^{7}$ CHAVES, Antônio. Direito à vida e ao próprio corpo. 2. ed. São Paulo: Revista dos Tribunais, 1994. p.13.

${ }^{8}$ SILVA, José Afonso da. Curso de direito constitucional positivo. 20. ed. São Paulo: Malheiros, 2001. p. 196. direta e indiretamente, como é o caso dos artigos 196 (saúde), 225 (meio-ambiente), 227 (criança e adolescente), entre outros.

O Código Penal dedicou o primeiro capítulo do primeiro título da sua Parte Especial - que trata dos Crimes Contra a Pessoa - à proteção da vida, ao determinar os crimes que contra ela atentam. Ressalte-se que todos os crimes que direta ou indiretamente atentem contra o bem jurídico vida recebem uma resposta mais severa do legislador, o que demonstra a carga valorativa conferida a este bem pela sociedade.

Partindo desta linha de raciocínio, em que a vida é um bem fundamental, protegido pelo direito, toda conduta social e norma de direito devem respeitá-la e ter a sua proteção como um fim.

Mas muitos são os questionamentos sobre os limites desta proteção e suas respostas variam conforme as linhas de valores dos diferentes grupos que os tentam responder, seja com base filosófica, científica ou religiosa.

Ronald Dworkin expõe que, quando algo tem um valor instrumental, é porque sua importância é proporcional à utilidade que puder proporcionar. Já o valor subjetivo seria aquele atribuído em função do desejo do sujeito em relação ao bem valorado. $\mathrm{O}$ valor intrínseco, por sua vez, é aquele atribuído ao bem independentemente do desejo, utilidade ou gosto de qualquer pessoa - simplesmente tem valor e deve ser respeitado. ${ }^{9}$

Este Autor prossegue afirmando que, na verdade, tem-se uma visão da vida a partir destas três formas de valoração. Afirma, por exemplo, que quando se julga uma pessoa positivamente em razão do bem que ela

9 DWORKIN, Ronald. Life's dominion: an argument about abortion, euthanasia, and individual freedom. New York: Alfred A. Knope, 1993. p.71. 
proporcionou à sociedade, está se analisando a sua vida com uma carga instrumental. Ao passo que quando se analisa a vida de outrem na medida em que se percebe a vontade que esta pessoa tem de viver, está se valorando de uma maneira pessoal e subjetiva a vida deste terceiro. E, finalmente, quando se julga a vida, seja de um feto, seja de uma pessoa, como algo que acima de tudo e em qualquer circunstância deve ser respeitada, está se conferindo um valor intrínseco à vida. ${ }^{10}$

Muitos, compartilhando desta visão, conferem à vida um caráter sagrado, sendo ela inviolável em virtude do que representa. Para alguns, a vida humana representa o resultado de uma criação divina, ou seja, é uma obra de Deus, que a criou como sua própria imagem e dela ninguém, por razão alguma, pode dispor. Outros conferem sacralidade à vida humana por ser esta obra da natureza, o resultado de um processo natural seletivo que culminou na raça humana.

Este princípio da sacralidade da vida humana está implícito na tradição hipocrática que influenciou a prática médica desde a Antiguidade até os tempos atuais.

Seja qual for a razão do valor sacro da vida, partindo desta perspectiva, muitas pessoas resistem severamente à idéia de aborto ou eutanásia. Assim, para os que compartilham de uma visão religiosa da sacralidade da vida, qualquer forma de agressão à vida é um insulto a Deus. John Locke, filósofo inglês, afirmava que a vida é propriedade de Deus e não do ser vivente, não cabendo à pessoa dela dispor. ${ }^{11}$

\footnotetext{
${ }^{10}$ Idem, p.72-73.

11 Idem, p. 195.
}

Seguindo uma linha similar de pensamento, a Igreja Católica se coloca contra a prática da eutanásia. Em 1956, o Papa Pio XII declarou:

“Toda forma de eutanásia direta, isto é, a subministração de narcóticos para provocarem ou causarem a morte, é ilícita porque se pretende dispor diretamente da vida (...) o homem não é senhor e proprietário, mas apenas usufrutuário de seu próprio corpo e da sua existência. Há a pretensão de um direito de disposição direta que visa à abreviação da vida como fim e como meio. Nas hipóteses que vou considerar, trata-se unicamente de evitar ao paciente dores insuportáveis, por exemplo, no caso de câncer inoperável ou doenças semelhantes. Se entre o narcótico e a abreviação da vida não existe nenhum nexo causal direto, e, se ao contrário, a administração de narcóticos ocasiona dois efeitos distintos: de um lado aliviando as dores e de outro abreviando a vida, serão lícitos. Precisamos, porém, verificar se entre os dois efeitos há uma proporção razoável, e se as vantagens de um compensam as desvantagens do outro. Precisamos, também, primeiramente, verificar se o estado atual da ciência não permite obter o mesmo resultado com o uso de outros meios, não podendo ultrapassar, no uso dos narcóticos, os limites do que for estritamente necessário". ${ }^{2}$

O Vaticano divulgou, ainda, em 1980, declaração sobre eutanásia no seguinte sentido:

"É necessário reafirmar com toda a firmeza que nada, nem pessoa alguma, pode autorizar a morte de um ser humano inocente, seja feto ou embrião, criança ou adulto, velho, enfermo, incurável ou agonizante. Ninguém, além disso, pode pedir este gesto homicida para si ou para os outros confiados a sua responsabilidade, nem pode consenti-lo implicitamente. Nenhuma autoridade pode legitimamente impô-lo nem

12 PIO XII. Discorsi ai medici, p.551 (discurso aos participantes do IX Congresso da Sociedade Italiana da Anestesiologia, em 24 fev.1952, apud Maria Celeste SANTOS, Transplante de órgãos $e$ eutanásia, p.242-243). 
permiti-lo. Trata-se, com efeito, de uma violação da lei divina, de uma ofensa à dignidade da pessoa humana, de um crime contra a vida, de um atentado contra a humanidade. Ante a iminência de uma morte inevitável, apesar dos meios empregados, é lícito em consciência tomar a decisão de renunciar alguns tratamentos que prolongariam precária e penosamente a existência, sem interromper, porém, os cuidados normais devidos ao enfermo em casos similare".

Há também outros documentos, como o da Conferência Episcopal da Alemanha (20/11/1978), que afirmam o direito a uma morte humana e a necessidade de se aplicar neste momento esforços para aliviar o sofrimento, dando-se na última fase da vida a melhor assistência possível, em seu caráter médico e humano.

O judaísmo também confere à vida um valor sagrado, por pertencer a Deus, não podendo, portanto, o homem dela dispor. Assim, a tradição hebraica é, por isso mesmo, contrária à eutanásia. ${ }^{13}$

Não valorando menos a vida, mas apenas dimensionando-a de maneira diversa, algumas visões mais liberais partem da premissa de que a vida não é apenas uma criação divina ou da natureza, mas uma criação do próprio sujeito, por meio de suas decisões, escolhas e investimentos. Neste sentido, não se busca proteger apenas a vida a partir de um sentido biológico ou orgânico, mas a partir de um sentido cultural. ${ }^{14}$ Assim, o próprio indivíduo, de acordo com a maneira que segue sua vida, confere um valor a ela.

13 A. WEISS, A Jewish Viewpoint, p.36 e ss., citado por Maria Celeste SANTOS, Transplante de órgãos e eutanásia, p.244.

14 DWORKIN, op. cit., p.93.
De acordo com esta visão, embora fundamental, o princípio da sacralidade da vida não deve ser tido como absoluto, pois em certas circunstâncias é legalmente e moralmente possível tirar a vida de uma pessoa, como nos casos de legítima defesa.

Ainda nesta linha de pensamento, muitos se mostram favoráveis à eutanásia, ou seja, não vêem ilícito algum, seja do ponto de vista legal, seja do ponto de vista moral, em se pôr fim à vida de um paciente terminal em profundo sofrimento e dor que assim solicita, desde que de acordo com certos requisitos médicos e legais. Tratar-se-ia, pois, de mais uma escolha do próprio paciente, decorrente da sua autonomia, que até então guiou sua vida e agora deverá guiar a sua morte.

Algumas correntes acreditam que a absolutização da vida pode acarretar em um fundamentalismo biológico perigoso, tendente a anular a especificidade do homem em relação ao animal, se ela existir de fato.

Aristóteles afirmava a impossibilidade de se fundar uma ética a partir de uma noção tão indeterminada quanto a vida, excluindo o simples fato de viver como critério suscetível de explicar a especificidade humana.

A biologista Henri Atlan constata que sacralizar a vida poderia significar o englobamento, na mesma glorificação, da vida de uma ameba, de uma mosca, de um peixe, de um passarinho, de um cachorro, de um homem, instaurando-se assim uma confusão de valores. ${ }^{15}$

15 ATLAN, Henri. Personne, espèces, humanité. In: GROS, de F. ${ }^{\text {o }}$ HUBER, G. (Dirs.) Vers in antidestin. Patrimoine genetique et droit de l'humanité. Paris: Odile Jacob, 1992. p.56, apud PALERMINI, Patricia. Misère de la bioéthique. Bruxelas: Labor, 2002. p. 25 
Patrícia Palermini, nesse mesmo sentido crítico à visão sacra da vida, afirma não haver prova de ser a melhor proteção ao ser humano contra tratamentos inumanos ou degradantes reduzi-lo à condição de animal vivente. ${ }^{16}$

$\mathrm{O}$ questionamento a respeito da absolutização do valor do bem vida parte do ponto em que a sua manutenção ultrapassa os limites da dignidade humana e afronta, ainda, outros direitos como autonomia, liberdade, intimidade e honra. Além disso, radicalizando-se o mesmo argumento podese deturpar a idéia de um direito garantido constitucionalmente (o direito à vida), confundindo-o com um dever (dever à vida).

Neste sentido, deve-se entender o valor da vida conjugando-o com outros valores que constituem o homem e fazem dele mais que um mero ser vivente. É justamente esta conjugação de direitos invioláveis do homem que hoje a medicina, em função da tecnociência, deve buscar.

Muitos são os defensores de um modo de morrer coerente com os valores cultivados em vida. Assim, em certos casos, a manutenção de uma vida, em nome de sua sacralidade, poderia significar um insulto a todas as convicções da pessoa e a todo o investimento humano que esta dedicou à sua vida. Ou seja, um respeito extremado em relação ao direito à vida pode significar, de outro lado, um desrespeito ao sujeito que a vive.

Muitas vezes o respeito à vida pode não estar na sua manutenção indistintamente, mas na aceitação de um fim digno a ela. Assim, em face da questão da eutanásia, a

\footnotetext{
16 PALERMINI, op. cit., p.25.
}

autonomia do sujeito e o valor intrínseco da vida em diversas situações irão se chocar.

A dificuldade do Estado em resolver este choque é evidente, na medida em que instituir um julgamento coletivo e generalizado a respeito de uma situação em que questões individuais são tão fundamentais pode acarretar uma postura protetiva-totalitária de um lado, ou liberalamoral de outro.

A apreensão, pela doutrina contemporânea, da idéia de dignidade como valor intrínseco da pessoa humana tem suas raízes no pensamento clássico, em especial no estoicismo, e no ideário cristão. Nesse sentido, para Tércio Sampaio Ferraz Júnior, "a personificação do homem foi uma resposta cristã à distinção, na Antigüidade, entre cidadãos e escravos. Com a expressão pessoa obteve-se a extensão moral do caráter de ser humano a todos os homens, considerados iguais perante Deus". ${ }^{17}$ Contribuiu para afirmar tal idéia o espanhol Francisco da Vitória, que, no séc. XVI, em plena expansão colonial espanhola, posicionou-se contra o processo de aniquilação, exploração e escravização dos povos indígenas, não apenas com base no estoicismo e no cristianismo, mas também em função do direito natural. ${ }^{18}$

Mas a dignitas humana ganhou novo sentido com o advento da Modernidade,

${ }^{17}$ FERRAZ JÚNIOR, Tércio Sampaio. Introdução ao estudo do Direito. São Paulo: Atlas, 2. ed., 1996, p. 156.

18 SARLET, Ingo Wolfgang. Dignidade da Pessoa Humana e Direitos Fundamentais na Constituição Federal de 1988. Porto Alegre: Livraria do Advogado, 2001, p.32. 
quando a influência do humanismo liberal fez da racionalidade a qualidade peculiar e inerente ao ser humano, tornando, assim, evidente o processo de racionalização e laicização pelo qual passou o pensamento em torno do direito natural e da dignidade da pessoa humana a partir dos séculos XVII e XVIII. Essa passagem encontra uma justificação teórica em Kant, como ressalta Ingo Sarlet:

"Construindo sua concepção a partir da natureza racional do ser humano, Kant sinala que a autonomia da vontade, entendida como a faculdade de determinar a si mesmo e agir em conformidade com a representação de certas leis, é um atributo apenas encontrado nos seres racionais, constituindo-se no fundamento da dignidade da natureza humana". ${ }^{19}$

Esses pressupostos, sustentáculos da idéia kantiana do homem, ser racional, como um "fim em si mesmo", trazem à tona, ainda, outras influências da Renascença sobre a filosofia da Idade Moderna, como, por exemplo, o humanismo, que exaltou o homem, substituto de Deus, mas, principalmente, o individualismo, que já havia encontrado expressão filosófica no nominalismo de Guilherme de Occam (para quem seriam reais apenas os seres designados por nomes próprios), e que compreende os homens como seres autônomos (liberdade seria, então, a faculdade de autodeterminação do ser humano ${ }^{20}$ ). É com o individualismo que se instaura, no seio do pensamento jurídico ocidental, o ponto de vista do particular, o que, de acordo com Celso Lafer,

\section{${ }^{19}$ Idem, p.32.}

${ }^{20}$ LAFER, Celso. A reconstrução dos direitos humanos. São Paulo: Cia. Das Letras, 2003, p.120. culminou com a elaboração do conceito de direito subjetivo, "figura jurídica afim com a dos direitos do homem e da personalidade, todos representativos, no seu desenvolvimento teórico, do individualismo. Este (o direito subjetivo) marca, na passagem da Idade Média para a Idade Moderna, a erosão de uma concepção hierárquica de sociedade na qual a igualdade só se colocava no momento da morte". ${ }^{21}$

Retornando ao ponto inicial, é possível verificar que a noção de que o ser humano é uma pessoa dotada de qualidades inerentes, essenciais e singulares é algo comum, hoje, em quase todas as sociedades e constituições, assim como o é a noção de direitos fundamentais. Mas, como se sabe, esta realidade nem sempre se apresentou com tais contornos, embora o direito moderno não explicite, claramente, a historicidade de sua formação. Portanto, a noção de dignidade humana não é inata, própria de todos os seres humanos, em todas as épocas e lugares, pois se trata de uma idéia elaborada e aprimorada, durante séculos, no âmbito do que se chamou de "Civilização Européia Ocidental Cristã". ${ }^{22}$

Embora não se faça menção a ele, o princípio da dignidade da pessoa humana, ponto de partida para construção dos direitos

\footnotetext{
21 Idem, p. 120.
}

22 O relativismo desse postulado do direito moderno é veementemente apontado por Michel Miaille, na seguinte crítica: "a noção de sujeito de direito ou de pessoa jurídica é apresentada nas introduções ao direito de maneira mais natural: o que há de mais lógico, afinal, do que ser o homem o centro do mundo jurídico, e ser, pois, em primeiro lugar o dado básico do sistema de direito?" (MIALlE, Michel. Uma Introdução Crítica ao Direito. Lisboa: Moraes, 1979, p.107). 
fundamentais e da personalidade, figura como antecedente lógico das noções de pessoa, direito subjetivo e direitos da personalidade, cujo desenvolvimento, no campo do direito civil, assumiu feições diversas daquelas presentes na sua concepção pela filosofia política e seu aperfeiçoamento pelo Direito Constitucional. ${ }^{23}$

\section{A VIDA SOB UMA ANÁLISE BIOPOLÍTICA}

\section{Para o intelectual francês Michel} Foucault, nos séculos XVII e XVIII, surgem técnicas de poder dirigidas aos indivíduos, dirigidas ao homem-corpo. Já no fim do século XVIII e início do século XIX, o que aparece é um poder dirigido à população, dirigido ao homem-espécie. Esse é o momento em que emerge o que Foucault chama de biopoder: "é o que se poderia denominar a assunção da vida pelo poder: se vocês preferirem, uma tomada de poder sobre o homem enquanto ser vivo, uma espécie de estatização do biológico". ${ }^{24}$

O biopoder diferencia-se do tradicional poder de soberania, em especial, por conta da relação distinta que entretém, cada um deles, com a vida e a morte, pois enquanto o poder soberano "faz morrer ou deixa viver", o biopoder "faz viver e deixa morrer", ou seja, são diferentes lógicas e concepções de morte, vida e corpo. Nas palavras de Foucault:

${ }^{23}$ GEDIEL, José Antônio Peres. Os transplantes de órgãos e a invenção moderna do corpo. Curitiba: Moinho do verbo, 2000.

${ }^{24}$ FOUCAULT, M. Em defesa da sociedade. São Paulo: Martins Fontes, 2002, p.285-286.
“(...) uma das mais maciças transformações do direito político do século XIX consistiu (...) em completar esse velho direito de soberaniafazer morrer ou deixar viver - com outro direito novo, que não vai apagar o primeiro, mas vai penetrá-lo, perpassá-lo, modificá-lo, e que vai ser um direito, ou melhor, um poder exatamente inverso: poder de 'fazer' viver e de 'deixar' morrer". 25

Essa transformação não se deu repentinamente, e Foucault a problematiza da seguinte maneira:

"Vocês já vêem, nos juristas do século XVII e sobretudo do século XVIII, formulada essa questão a propósito do direito de vida e de morte. Quando os juristas dizem: quando se contrata, no plano do contrato social, ou seja, quando os indivíduos se reúnem para constituir um soberano, para delegar a um soberano um poder absoluto sobre eles, por que o fazem? Eles o fazem porque estão premidos pelo perigo ou pela necessidade. Eles o fazem, por conseguinte, para proteger a vida. É para poder viver que constituem um soberano. E, nesta medida, a vida pode efetivamente entrar nos direitos do soberano? Não é a vida que é fundadora do direito do soberano? E não pode o soberano reclamar efetivamente de seus súditos o direito de exercer sobre eles o poder de vida e de morte, ou seja, pura e simplesmente, o poder de matá-los? Não deve a vida ficar fora do contrato, na medida em que ela é que foi o motivo primordial, inicial e fundamental do contrato?". ${ }^{26}$

As perguntas formuladas por Foucault são tratadas não no plano da filosofia política, mas no nível das tecnologias de poder. Foucault identifica, ainda, que "Aquém, portanto, do grande poder absoluto, dramático, sombrio que era o poder da soberania, e que consistia em poder de fazer

\footnotetext{
25 Idem, p. 287.

26 Idem, p.287-288.
} 
morrer, eis que aparece agora, com essa tecnologia do biopoder, com essa tecnologia do poder sobre a 'população' enquanto tal, sobre o homem enquanto ser vivo, um poder contínuo, científico, que é o poder de 'fazer viver'". ${ }^{27}$ Nessa linha de raciocínio, o biopoder é, cada vez mais, uma estratégia de poder traduzida como o "direito de intervir para fazer viver, e na maneira de viver, e no ‘como' da vida, a partir do momento em que, portanto, o poder intervém sobretudo nesse nível para aumentar a vida, para controlar seus acidentes, suas eventualidades, suas deficiências". ${ }^{28}$

Assim sendo, Foucault ressalta que o aparecimento do biopoder no contexto da "desqualificação progressiva da morte" tem o seguinte sentido:

“(...) a morte, como termo da vida, é evidentemente o termo, o limite, a extremidade do poder. Ela está do lado de fora, em relação ao poder: é o que cai fora de seu domínio, e sobre o que o poder só terá domínio de modo geral, global, estatístico. Isso sobre o que o poder tem domínio não é a morte, é a mortalidade. E, nessa medida, é normal que a morte, agora, passe para o âmbito do privado e do que há de mais privado. Enquanto, no direito de soberania, a morte era o ponto em que mais brilhava, da forma mais manifesta, o absoluto poder do soberano, agora a morte vai ser, ao contrário, o momento em que o indivíduo escapa a qualquer poder, volta a si mesmo e se ensimesma, de certo modo, em sua parte mais privada. O poder já não conhece a morte. No sentido estrito, o poder deixa a morte de lado". ${ }^{29}$

${ }^{27}$ FOUCAULT, Michael. Em defesa da sociedade. São Paulo: Martins Fontes, 2003, p.294.

\footnotetext{
28 Idem, p. 294.

${ }^{29}$ Idem, p.295-296.
}

Peter Pál Pelbart concebe a emergência do biopoder como passagem da lógica da soberania para a lógica biológica, o que permitiu, em nome de um discurso em defesa da vida, o exercício de um poder de morte:

"Já na época clássica, o poder deixa de basear-se predominantemente na retirada e na apropriação, para funcionar na base da incitação, do reforço, do controle, da vigilância, visando, em suma, a otimização das forças que ele submete. Como diz Foucault, nesse novo regime o poder é destinado a produzir forças e as fazer crescer e ordená-las, mais do que a barrá-las ou destruí-las. Gerir a vida, mais do que exigir a morte. E quando exige a morte, é em nome da defesa da vida que ele se encarregou de administrar. Curiosamente, é quando mais se fala em defesa da vida que ocorrem as guerras mais abomináveis e genocidas - o poder de morte se dá como um complemento de um poder que se exerce sobre a vida de maneira positiva. (...) Os poderes levam suas guerras como gestoras da vida e da sobrevida, dos corpos e da raça. É o discurso da vida, da sobrevida, da sobrevivência: poder matar para poder viver, princípio alçado a estratégia de Estado. Se antes tratava-se de defender a soberania de um Estado (lógica da soberania) trata-se agora de garantir a sobrevivência de uma população (lógica biológica)." 30

Tal constatação parece ser coerente com a análise de Foucault, para quem "As guerras já não se travam em nome do soberano a ser defendido; travam-se em nome da existência de todos; populações inteiras são levadas à destruição mútua em nome da necessidade de viver. Os massacres se tornaram vitais". ${ }^{31}$

${ }^{30}$ PELBART, Peter Pál. Vida capital: ensaios de biopolítica. São Paulo: Iluminuras, 2003, p.56-57.

${ }^{31}$ FOUCAULT, Michael. História da Sexualidade I: a vontade de saber. Trad. Maria Thereza da Costa Albuquerque e J. A. Guilhon Albuquerque. Rio de Janeiro: Graal, 1988, p.179. 
Foucault inseriu, portanto, a biopolítica no cerne de uma relação problemática entre vida e história. Aliás, a vida teria ingressado não apenas na história, mas também na ordem do saber, do poder e no domínio da política, pois a espécie veio a ser a grande variável nas estratégias políticas. Como ressaltou Peter Pál Pelbart, "Se desde Aristóteles, diz ainda Foucault, numa fase retomada com insistências por seus intérpretes, e revirada por Agamben, o homem era um animal vivente capaz de uma existência política, agora é o animal em cuja política o que está em jogo é o caráter de ser vivente". ${ }^{32}$

$\mathrm{O}$ reconhecimento do direito à vida pelo Estado não se deu apenas como conseqüência da valorização do homem e sua dignidade, difundida pelo humanismo e defendida pelas declarações dos direitos do homem e do cidadão.

Juntamente com todo o processo histórico que culminou na sua proteção jurídica pelo Estado, a vida sofreu importantes inserções de poderes e controles e tornou-se não apenas no bem jurídico mais valorizado, mas no objeto de poder mais manipulado e controlado pela lógica capitalista. Esta forma de poder e controle sobre a vida, uma verdadeira gestão da vida, que se deu principalmente a partir do século XVIII (período que coincide, portanto com a época das declarações e reconhecimento dos direitos dos homens).

Giorgio Agamben, em seu livro "Homo Sacer", trabalha exatamente com o momento em que ocorre a "estatização da vida".

32 PELBART, op. cit., p.58.
O direito à vida parece não ser um direito subjetivo individual, pois teria sido transferido ao soberano. Opondo-se a tal possibilidade, o discurso do constitucionalismo moderno considera a vida como um direito fundamental indisponível, irrenunciável e intransferível. Dessa forma, percebe-se que houve uma passagem, não na seara jurídica, mas política. Isso porque, no contrato social, os indivíduos não abriram mão do seu direito à vida, mas invisivelmente, nos pactos, não nos contratos, no plano da organização social, a vida já escapou ao sujeito. Assim, a autonomia privada é, atualmente, um discurso legitimador que busca negar que "A grande metáfora do Leviatã, cujo corpo é formado por todos os corpos dos indivíduos, deve ser lida sob esta luz. São os corpos absolutamente matáveis dos súditos que formam o novo corpo político do Ocidente". ${ }^{33}$

Alguns momentos fundamentais da história política moderna são ressaltados por Agamben para comprovar sua observação. Nesse sentido, a criação do instituto do Habbeas Corpus, de 1679, e a promulgação da Declaração Universal dos Direitos do Homem e do Cidadão, de 1789, guardam "uma incompreensível intrusão de princípios biológico-científicos na ordem política" e só adquirem seu real sentido quando são restituídos ao "comum contexto biopolítico (ou tanatopolítico) ao qual pertencem". 34

Nessa linha de raciocínio, Agamben diz ser

33 AGAMBEN, Giorgio. Homo Sacer: o poder soberano e a vida nua I. Trad. Henrique Búrigo. Belo Horizonte: Editora UFMG, 2002, p.131.

${ }^{34}$ Idem, p. 129. 
"O primeiro registro da vida nua como novo sujeito político (...) o writ de Hábeas Corpus de 1679. Seja qual for a origem da fórmula, que é encontrada já no século XIII para assegurar a presença física de uma pessoa diante de uma corte de justiça, é singular que em seu centro não esteja nem o velho sujeito das relações e das liberdades feudais, nem o futuro citoyen, mas o puro e simples corpus". ${ }^{35}$ (Portanto), "corpus é o novo sujeito da política, e a democracia moderna nasce propriamente como reivindicação e exposição deste 'corpo': hábeas corpus ad subjiciendum, deverás ter um corpo para mostrar. Que justamente o Hábeas Corpus, entre os vários procedimentos jurisdicionais voltados à proteção da liberdade individual, recebesse forma de lei e se tornasse, assim, inseparável da história da democracia ocidental, seguramente deve-se a circunstâncias acidentais; mas é também certo que, deste modo, a nascente democracia européia colocava no centro de sua luta com o absolutismo não o bíos, a vida qualificada de cidadão, mas zoé, a vida nua em seu anonimato, apanhada, como tal, no bando soberano". ${ }^{36}$

A seu turno, a Declaração Universal dos Direitos do Homem e do Cidadão, de 1789, reflete outro problema. Agamben diz que,

"No sistema do Estado-nação, os ditos direitos sagrados e inalienáveis do homem mostram-se desprovidos de qualquer tutela e de qualquer realidade no mesmo instante em que não seja possível configurá-los como direitos dos cidadãos de um Estado. Isto está implícito, se refletirmos bem, na ambigüidade do próprio título da declaração de 1789: Declaration dês droits de l'homme et du citoyen, onde não está claro se os dois termos denominam duas realidades autônomas ou formam em vez disso um sistema unitário, no qual o primeiro já está desde o início contido e oculto no segundo; e, neste caso, que tipo de relação existe entre eles (...) As declarações dos direitos devem então ser vistas como o local em que se efetua a

\footnotetext{
35 Idem, p. 129.

36 Idem, p.130.
}

passagem da soberania régia de origem divina à soberania nacional. Elas asseguram a exceptio da vida na nova ordem estatal que deverá suceder à derrocada do ancien regime. Que, através, delas, o súdito se transforme, como foi observado, em cidadão, significa que o nascimento - isto é, a vida natural como tal torna-se aqui pela primeira vez (com uma transformação cujas consequiências biopolíticas somente hoje podemos começar a mensurar) o portador imediato da soberania. O princípio de natividade e o princípio de soberania, separados no antigo regime (onde o nascimento dava lugar somente ao sujet, ao súdito) unem-se agora irrevogavelmente no corpo do 'sujeito soberano' para constituir o fundamento do novo Estado-nação". ${ }^{37}$

A partir dessas reflexões, Agamben retoma o pensamento de Binding, para quem "não resta ao direito outra possibilidade senão a de considerar o homem vivente como soberano sobre a própria existência", para dizer que "A soberania do vivente sobre si configura, como a decisão soberana sobre o estado de exceção, um limiar de indiscernibilidade entre exterioridade e interioridade, que a ordem jurídica não pode, portanto, nem excluir nem incluir, nem vetar e nem permitir". ${ }^{38}$ Dessa forma, quando Binding desenvolve uma construção teórica para autorizar "o aniquilamento da vida indigna de ser vivida", Agamben vê não apenas uma doutrina em favor da eutanásia, mas também "a estrutura biopolítica fundamental da modernidade - a decisão sobre o valor (ou sobre o desvalor) da vida como tal - encontra, então, a sua primeira articulação jurídica". ${ }^{39}$

37 AGAMBEN, Giorgio. Homo Sacer: o poder soberano e a vida nua I. Trad. Henrique Búrigo. Belo Horizonte: Editora UFMG, 2002, p.134-135.

\footnotetext{
38 Idem, p. 143.

39 Idem, p. 144
} 
O papel e o poder da vontade, antes concebidos em abstrato, deveriam ser considerados em relação a interesses concretos dos indivíduos, embora tais interesses continuassem a prescindir, para serem assegurados, de um poder atribuído ao seu titular, pela ordem jurídica.

\section{CONCLUSÃO}

Percebe-se, então, que a valorização da vida, pressuposto para se inserir em qualquer discussão em torno da eutanásia, é um ponto delicado que pode ser analisado a partir de diferentes ângulos. O discurso humanista, com forte influência cristã e jusnaturalista certamente fornece um importante acervo de argumentação, mas deve ser visto como um discurso permeado também por outras lógicas, como a lógica do poder e do controle.

O reconhecimento da vida como um bem jurídico fundamental e inalienável decorre sim da valorização do homem e de sua dignidade difundida pelo humanismo liberal e defendida pelas declarações dos direitos dos homens, mas decorre também do fato de ter a vida se tornado um objeto útil de controle e manipulação.

Discutir a eutanásia, portanto, torna-se ainda mais complicado pela nebulosidade e complexidade que o valor vida adquiriu na sociedade moderna ocidental capitalista.

Discutir a legalização da eutanásia, dessa forma, é atuar tanto na lógica moderna da proteção do sujeito e de sua autonomia, quando se pretende reconhecer a este um direito subjetivo de morrer, quanto na lógica biopolítica, pois nesta linha de raciocínio, o Estado continuaria sendo a força legitimadora deste direito, uma vez que este direito de morrer seria uma simples decorrência de um poder do Estado de "deixar morrer".

Como se já não bastasse todo este paradoxo em que a proteção da vida foi estruturada durante todo o percurso da modernidade (da qual somos herdeiros, e, portanto, é com seus instrumentos que pensamos), a biotecnologia e a tecnociência com suas técnicas de domínio e manipulação da vida tornam ainda mais complexa e inadequadas as categorias modernas com as quais se discute a legitimidade e legalidade da eutanásia: onde termina a vida e começa a morte? O que é considerado dignidade? Os conceitos que já eram abstratos e tidos como cláusulas gerais, tornam-se ainda mais nebulosos e inacessíveis pela nova lógica de uma ciência fáustica e manipuladora.

A questão da eutanásia é de natureza polêmica independente do campo de discussão em que é levantada e dos sujeitos que o compõem. A sua discussão reflete uma imensa complexidade, independente da realidade social em que é instigada. Não obstante, as dificuldades de se obter um debate legítimo e democrático se tornam ainda mais evidentes quando se transporta este tema para um universo onde a miséria material e cultural, decorrente de uma desigualdade social gritante, fazem parte da realidade cotidiana - este universo corresponde ao contexto latino-americano, em que o Brasil está inserido.

A América Latina é marcada pela presença da morte precoce e injusta, morte provocada lenta e sutilmente por sistemas, estruturas e regimes políticos: altas taxas de mortalidade infantil, baixa expectativa de vida, más condições de trabalho, ou simplesmente ausência de trabalho, uma estrutura de saúde 
pública fraca e desorganizada. Como países periféricos do sistema capitalista, as vidas das pessoas que a compõe também importam menos ao controle.

Em países como o Brasil, em que a eutanásia é feita nos corredores dos hospitais, nos quais os médicos optam pelo paciente com maior chance de viver, por não haver estrutura suficiente para o atendimento de todos, a questão da eutanásia deve ser analisada com cautela. Isso porque em tal conjuntura, a eutanásia, defendida no campo teórico em nome da proteção da dignidade do sujeito-paciente, pode ser utilizada, na prática, contra os direitos humanos eliminação de vidas que só custam e não contribuem para o sistema, já que o exército de reserva é grande o bastante.

Enfim, em países pobres os questionamentos sobre a eutanásia parecem dizer respeito a uma elite que pode arcar com as despesas dos remédios e aparelhos que sustentam uma sobrevida. Até porque a maioria das pessoas destes países convive com o processo de morte não em leitos de hospitais, mas no processo do seu (sobre-)viver. Assim sendo, como garantir uma morte digna, quando não se consegue oferecer a todos condições materiais para levar uma vida digna? Em uma situação em que "a necessidade cotidiana de sobreviver supera as possibilidades da liberdade, do usufruto, das conquistas democráticas e dos processos de decisão que não estejam imediatamente ligados à sobrevivência", ${ }^{40}$ pode parecer que o debate da eutanásia seja secundário, demasiado retórico e até mesmo hipócrita.

Todavia, a negação de direitos fundamentais a um número significativo de pessoas no contexto latino americano não deve ser desculpa para afastar ou diminuir a importância da discussão da eutanásia, pois antes de ingressar no código binário jurídico do "lícito-ilícito", o tema da eutanásia deve ser analisado sob um prisma político, moral e ético. E é justamente na seara política, moral e ética em que residem preocupações comuns. Aí dormem os problemas não resolvidos e a partir desse mesmo lugar é preciso rasgar as teias do poder e dar materialidade a toda a potência que emana dos corpos que não querem mais se sujeitar.

${ }^{40}$ GUIMARÃES, Maria Carolina S.; NOVAES, Sylvia Caiuby. Autonomia reduzida e vulnerabilidade: liberdade de decisão, diferença e desigualdade. Simpósio: revista publicada pelo Conselho Federal de Medicina, v.7, n.1, p.23, 1999. 